\title{
Peramalan Produksi Cabai Merah di Jawa Barat Menggunakan Metode Singular Spectrum Analysis (SSA)
}

\author{
${ }^{1}$ ASNAFIYA ASROF, ${ }^{2}$ RABBANI ISCHAK, ${ }^{3}$ GUMGUM DARMAWAN \\ 1,2Mahasiswa Statistika Terapan Universitas Padjajaran \\ ${ }^{3}$ Dosen Statistika Terapan Universitas Padjajaran \\ Email: 1asnafiya06@gmail.com, 2banzadd@gmail.com,3gumstat@gmail.com
}

\begin{abstract}
ABSTRAK
Peramalan merupakan suatu proses untuk memperkirakan peristiwa di waktu mendatang berdasarkan data yang relevan di waktu lampau. Produksi Cabai Merah di Jawa Barat merupakan salah satu data deret waktu. Peramalan pada data berpola musiman ini dilakukan dengan metode Singular Spectrum Analysis. Pada akhir proses Singular Spectrum Analysis, diperoleh pengelompokkan data sebanyak 4 grup, yang menggambarkan fluktuasi data untuk 12 periode peramalan. Tingkat akurasi data peramalan diukur dari kriteria Mean Absolute Percentage Error (MAPE) dengan nilai terkecil. Diperoleh nilai MAPE pada model peramalan SSA terhadap data aktual sebesar 18.23\%. Dengan begitu model Singular Spectrum Analysis merupakan model terbaik untuk meramalkan produksi cabai merah di Jawa Barat periode Januari 2016 sampai Desember 2016.
\end{abstract}

Kata Kunci: Singular Spectrum Analysis, Peramalan, Produksi Cabai Merah.

\section{PENDAHULUAN}

Kebutuhan masyarakat akan cabai merah memang tidak dapat dihindari, karena cabai merah merupakan salah satu yang menjadi bagian dari bahan pokok pada seluruh lapisan masyarakat. Memiliki nama latin Capsicum annuum L., cabai merah memiliki manfaat bagi kesehatan karena mengandung vitamin $\mathrm{C}$, vitamin $\mathrm{A}$, dan senyawa lain yang membantu daya tahan tubuh terhadap serangan penyakit. Selain itu juga digunakan untuk bumbu dapur maupun bahan pelengkap dalam setiap hidangan yang disajikan. Sehingga peminatan cabai merah begitu tinggi di masyarakat.

Jawa Barat merupakan produsen cabai merah terbesar se-Indonesia. Dengan begitu, terbentuklah komitmen untuk meningkatkan volume ekspor cabai merah di Jawa Barat. Hal ini dilakukan dengan terus mendorong produktivitas di seluruh kabupaten se-Jawa Barat. Sehingga pasokan cabai merah terbilang cukup untuk memenuhi kebutuhan nasional. Selama ini budidaya cabai merah dilakukan secara musiman sehingga produksi maupun harga sangat berfluktuasi sepanjang tahun. Produksi cabai merah sebagian besar digunakan untuk konsumsi masyarakat setempat dan sebagian lagi diekspor ke negara-negara beriklim dingin dalam bentuk kering. Oleh karena itu, hampir setiap hari produk cabai merah ini dibutuhkan, sehingga kebutuhan masyarakat akan cabai merah pun meningkat sejalan dengan semakin bervariasinya jenis dan menu makanan yang memanfaatkannya produk ini.

Berdasarkan hasil survey Sosial Ekonomi Nasional (Susenas), konsumsi cabai per kapita per tahun relative stabil dengan laju pertumbuhan rata-rata $0,81 \%$ per tahun. Menurut data angka tetap hortikultura Provinsi Jawa Barat sebesar 88.000 ton atau 34,74\% dari total produksi cabai besar, diikuti oleh Cianjur 25,96\%, Kabupaten Tasikmalaya 7,55\%, dan Kabupaten Bandung 6,85\%. Pada periode Januari-Desember musim tanam tahun 2016, Jawa Barat berhasil merealisasikan luas panen cabai rawit 9.123 ha dari luas tanam 9.635 ha. Tingkat produktivitas yang dicapai sebesar 132,36 ha, luas panen 20.459 ha dengan tingkat produktivitas 139,46 kuintal per ha dari luas tanam 21.536 ha dan total produksi 285.337 ton. [1]

Data produksi cabai merah di Jawa Barat ini merupakan salah satu yang termasuk data deret waktu. Data deret waktu sendiri memiliki definisi berupa urutan data-data pengamatan yang 
berdasarkan pada interval waktu yang sama dimana hasil pengamatannya memiliki korelasi maupun saling bebas. Analisis data deret waktu memungkinkan peneliti untuk mengetahui perkembangan suatu kejadian serta hubungan atau pengaruhnya terhadap kejadian lainnya. Dalam analisis deret waktu terdapat beberapa metode yang salah satunya adalah metode peramalan. Peramalan merupakan bagian penting sebelum pengambilan keputusan. Efektif atau tidaknya keputusan tergantung pada faktor yang tidak dapat dilihat pada saat pengambilan keputusan. Peranannya sangat luas dalam berbagai bidang.

Metode SSA adalah salah satu teknik peramalan yang menggabungkan unsur unsur dari analisis klasik time series, multivariate, sistem dinamis dan signal processing. Metode ini merupakan metode dengan pendekatan non-parametrik untuk melakukan peramalan (forecasting) berdasarkan identifikasi komponennya, baik itu trend, musiman atau lainnya. Menurut Golyandina, SSA adalah suatu metode yang sangat berguna untuk memecahkan masalah berikut ini: 1) menemukan trend dari resolusi berbeda; 2) smoothing; 3) ekstraksi komponen musiman; 4) ekstraksi simultan untuk siklus dengan periode kecil dan besar; 5) ekstraksi perioditas dengan amplitudo yang bervariasi; 6) ekstraksi simultan untuk tren dan perioditas yang kompleks; 7) mendeteksi change-point. [2]

Makalah ini bertujuan untuk mendapatkan hasil ramalan pada produksi cabai merah di Jawa Barat menggunakan metode yang tingkat akurasinya baik, yaitu SSA. Untuk selanjutnya, akan diberi judul "Peramalan Produksi Cabai merah Di Jawa Barat Menggunakan Metode Singular Spectrum Analysis (SSA)”,

\section{METODOLOGI}

Data yang digunakan dalam peramalan ini merupakan data produksi cabai merah di provinsi Jawa Barat. Data ini merupakan pergerakan produksi bulanan dengan periode yang dimulai pada Januari 2010 hingga Desember 2015 [8]. Data tersebut merupakan data deret waktu yang disajikan pada Lampiran 1, yang dibagi menjadi dua bagian berikut.

a. Data in sample : Januari 2010 - Desember 2014

b. Data out sample : Januari 2015 - Desember 2015

Metode peramalan yang akan digunakan dalam meramalkan produksi cabai merah di Jawa Barat adalah metode SSA. Pengolahan data dalam peramalan ini menggunakan Software $R$ Studio dan Minitab.

Metode SSA merupakan metode peramalan yang cukup fleksibel. Zhigljavsky menyatakan bahwa SSA memiliki kelebihan dibanding metode yang lain, diantaranya SSA memerlukan daya komputer yang intensif, tidak memerlukan asumsi stasioneritas dan tidak memerlukan transformasi logaritma [4]. Dengan kata lain, SSA merupakan metode yang powerfull dengan pendekatan nonparametrik [5]. Dasar dari SSA adalah dekomposisi, dimana data deret waktu diuraikan menjadi komponen- komponennya yaitu tren, musiman, siklis dan noise [6], berikut algoritma dasarnya.

\section{Dekomposisi}

Tahap dekomposisi terdapat dua langkah, yaitu dengan embedding dan singular value decomposition. Pada tahap ini parameter yang digunakan adalah window length $L$.

\section{Embedding}

Pada tahap ini dilakukan dengan mengubah deret waktu awal yang berdimensi satu $Y=$ $\left(y_{1}, \ldots, y_{N}\right.$ menjadi deret multidimensi $X_{1}, \ldots, X_{K}$ dengan vektor lag $X_{i}=\left(y_{1}, \ldots, y_{i+L-1}\right)^{T}$. Dari vektor lag kemudian dibuat matriks lintasan $=\left[X_{1}, \ldots, X_{K}\right]$. Matriks lintasan ini berukuran $L x K$, dimana $1<L<N$ dan $K=N-L+1$ dengan panjang $N$. Matriks $X$ dituliskan sebagai :

$X=\left(x_{i j}\right)_{i, j=1}^{L, K}=\left(\begin{array}{c}X_{1} \\ X_{2} \\ : \\ \cdot \\ X_{K}\end{array}\right)=\left(\begin{array}{cccc}y_{1} & y_{2} & \ldots & y_{K} \\ y_{2} & y_{3} & \ldots & y_{K+1} \\ : & : & : & : \\ \cdot & \cdot & \cdot & \cdot \\ y_{L} & y_{L+1} & \ldots & y_{N}\end{array}\right)$ 
Misalkan data deret waktu awal pada produksi cabai merah didefinisikan sebagai $F=$ $\left(f_{0}, f_{1}, \ldots, f_{N-1}\right)$, kemudian diubah ke dalam multidimensi sehingga diperoleh output sebuah matriks Hankel yang semua elemen pada anti diagonalnya bernilai sama.

\section{Singular Value Decomposition (SVD)}

Hasil dari langkah ini adalah Singular Value Decomposition dari matriks lintasan. Matriks ini dalam setiap barisannya mengandung singular value, eigenvector, dan principal component. Misalkan $\lambda_{1}, \lambda_{2}, \ldots, \lambda_{L}$ adalah eigenvalue dari matriks $S=X X T$, sehingga singular value dinotasikan dengan $\sqrt{\lambda_{i}}$. Eigenvectors dari masing-masing eigenvalues dinotasikan dengan $U_{1}, U_{2}, \ldots, U_{L}$. Sedangkan principal component dinotasikan dengan $V_{i}=\mathbf{X}^{T} U_{i} / \sqrt{\lambda_{i}}(i=1, \ldots, d)$. SVD dari matriks lintasan dituliskan sebagai: $\mathbf{X}=\mathbf{X}_{1}+\mathbf{X}_{2}+\ldots+\mathbf{X}_{d}$, Dimana $\mathbf{X}_{i}=\sqrt{\lambda_{i}} U_{i} V_{i}^{\mathrm{T}}$

- Matriks $\mathbf{X}_{i}$ mempunyai rank 1, karena merupakan matriks elementer. Kumpulan dari $\left(\sqrt{\lambda_{i}}, U_{i}, V_{i}\right)$ disebut eigentriple ke i dari SVD. [Goldyana]. SVD dari matriks lintasan dapat ditulis dengan persamaan berikut.

$X=X_{1}+X_{2}+\cdots+X_{d}$

$X=\sum_{i=1}^{d} \sqrt{\lambda_{i}} U_{i} V_{i}^{T}$

$$
X=\sqrt{\lambda_{1}} U_{1} V_{1}^{T}+\sqrt{\lambda_{2}} U_{2} V_{2}^{T}+\cdots+\sqrt{\lambda_{d}} U_{d} V_{d}^{T}
$$

\section{Rekonstruksi}

Tahap rekonstruksi terdapat dua langkah, yaitu dengan grouping dan diagonal averaging.. Pada tahap ini parameter yang digunakan adalah grouping effect. Hasil rekonstruksi mendekatkan hasil peramalan dengan data aslinya. Oleh karena itu pengelompokkan komponen-komponen yang tepat akan mendukung hasil peramalan yang baik, dengan menunjukkan MAPE dari nilai ramal dengan data aslinya [7].

\section{Grouping}

Langkah pertama dalam tahap rekonstruksi adalah grouping. Dasar pengelompokkan pada grouping adalah eigenvector. Tujuan dari langkah grouping ini adalah untuk memisahkan komponen aditif dari deret waktu dengan cara memisahkan matriks yang telah dihitung pada tahap SVD ke dalam beberapa kelompok, kemudian menjumlahkan matriks dalam setiap kelompok. Matriks $X_{i}$ akan dipartisi ke $\mathrm{m}$ disjoint subset $I_{1}, \ldots, I_{m}$.

Jika $I=\left\{i_{1}, \ldots, i_{p}\right\}$, maka matriks resultan $\mathbf{X}_{I}$ bersesuaian dengan grup $I$ didefinisikan sebagai $\mathbf{X}_{I}=\mathbf{X}_{i_{1}}+\ldots+\mathbf{X}_{i_{p}}$. Matriks ini dihitung untuk $I=I_{1}+\ldots+I_{m}$, sehingga persamaan (2) menjadi:

$\mathbf{X}=\mathbf{X}_{I_{1}}+\ldots+\mathbf{X}_{I_{m}}$.

Prosedur pemilihan set $I_{1}, \ldots, I_{m}$ disebut pengelompokkan eigentriple (eigentriple grouping) yang merupakan representasi dari matriks lintasan sebagai jumlah dari beberapa matriks resultan.

\section{Diagonal Averaging}

Langkah terakhir pada SSA ini adalah diagonal averaging. Langkah ini akan mengubah setiap matriks hasil dekomposisi yang telah dikelompokkan pada tahap grouping menjadi deret yang baru dengan panjang $N$, yang dimisalkan dengan $F$ berikut. 
$F=\left[\begin{array}{cccc}f_{11} & f_{12} & \ldots & f_{K} \\ f_{21} & f_{22} & \ldots & f_{K+1} \\ \vdots & \vdots & \ddots & \vdots \\ y_{L} & y_{L+1} & \ldots & f_{N}\end{array}\right]$

Jika $\boldsymbol{F}$ adalah matriks $L \times K$ dengan elemen $y_{i j}, 1 \leq i \leq L, 1 \leq j \leq K, L^{*}=\min (L, K), K^{*}=$ $\max (L, K)$, dan $N=L+K-1$. Rata-rata diagonal averaging diperoleh dengan rumus berikut.

$$
g_{k}=\left\{\begin{array}{l}
\frac{1}{k+1} \sum_{m=1}^{k+1} y^{*}{ }_{m, k-m+2}, \text { untuk } 0 \leq k<L^{*}-1 \\
\frac{1}{L^{*}} \sum_{m=1}^{L^{*}} y^{*}{ }_{m, k-m+2}, \text { untuk } L^{*}-1 \leq k<K^{*} \\
\frac{1}{N-k} \sum_{m=k-K^{*+2}}^{N-K^{*+1}} y^{*}{ }_{m, k-m+2}, \text { untuk } K^{*} \leq k<N
\end{array}\right.
$$

Berdasarkan persamaan (5) dan (6), Misalnya pada matriks $\boldsymbol{F}$, dipilih $\mathrm{k}=1$, maka $g_{1}=f_{11}$, untuk $\mathrm{k}=2$, maka $g_{2}=\left(\frac{f_{12}+f_{21}}{2}\right)$, untuk $\mathrm{k}=3$, maka $g_{3}=\left(\frac{f_{13}+f_{22}+f_{31}}{3}\right)$, dan begitu seterusnya. Sedangkan berdasarkan persamaan (6), jika diaplikasikan pada matriks resultan $X_{I m}$, akan terbentuk sebuah deret $\tilde{Y}^{(k)}=\left(\tilde{Y}_{1}^{(k)}, \tilde{Y}_{2}^{(k)}, \ldots, \tilde{Y}_{N}^{(k)}\right)$ sehingga deret asli didekomposisi menjadi jumlah dari $m$ deret.

$y_{n}=\sum_{k=1}^{m} \tilde{Y}_{n}^{(k)}$

\section{Penentuan Parameter dalam SSA}

\section{Window Length (L)}

Sebelum memasuki tahap demi tahap dalam SSA, terlebih dahulu ditentukan nilai $L$. terdapat dua parameter dalam SSA. Sedangkan Window Length $L$ ini merupakan parameter utama untuk menentukan banyaknya dimensi matriks lintasan. Nilai $L$ merupakan dimensi dari matriks trajectory, yang merupakan matriks dari perkalian Hankel. Penentuan nilai $L$ dilakukan pada proses pengecekan melalui trial and error dengan ketentuan $2<L<N / 2$.

\section{Grouping Effect (r)}

Grouping effect merupakan parameter kedua dalam SSA yang berperan penting dalam menentukan pola pada plot data. Setelah penggunaan parameter $L$ dalam dekomposisi, pada hasil SVD akan menyajikan serangkaian seri awal yang telah dipisahkan dengan baik [5]. Eigentriples yang telah terbentuk sebelumnya dalam tahap SVD akan membantu menentukan parameter grouping effect.

\section{Algoritma Peramalan Model SSA}

\section{Ketepatan Pencapaian Model Peramalan}

Tingkat keakuratan model peramalan dapat dijelaskan dengan membandingkan nilai yang diproyeksikan dengan nilai aktual. Keakuratan sebuah model peramalan ditentukan oleh nilai terkecil dari masing-masing metode akurasi data, semakin kecil nilai tersebut semakin akurat sebuah model melakukan prediksi. Untuk tingkat akurasi peramalan dapat diukur dari nilai Mean Absolute Persentage Error (MAPE), yaitu rata persentase kesalahan pertama dari beberapa periode,

$M A P E=\frac{100 \%}{n} \sum_{t=1}^{n} \frac{\left|\left(Y_{t}-\widehat{Y}_{t}\right)\right|}{Y_{t}}$

dengan: 
$Y_{t}=$ Nilai Observasi; dan $\widehat{Y}_{t}=$ Nilai peramalan.

Apabila nilai MAPE semakin kecil, maka semakin baik tingkat akurasi prediksinya

\section{Linear Recurrent Formula (LRT)}

Peramalan SSA menggunakan Linear Recurrent Formula (LRF) ini, deret waktu yang digunakan adalah deret hasil rekonstruksi yang diperoleh dari hasil diagonal averaging. Lalu akan ditentukan $M$ buah titik data baru yang akan diramalkan. Model ramalannya adalah sebagai berikut.

$g_{i}=\left\{\begin{array}{cc}\tilde{y}_{i} & \text { untuk } 0, \cdots, N \\ \sum_{j=1}^{L-1} a_{j} g_{i-j} & \text { untuk } N+1, \cdots, N+M\end{array}\right.$

Penaksir koefisien LRF ( $a_{1}, \ldots$, ad )menggunakan eigenvector yang diperoleh pada tahapan SVD. Misalkan $U=\left(u_{1}, u_{2}, \ldots, u_{L-1}, u_{L}\right)^{T}, U^{\bar{v}}=\left(u_{1}, u_{2}, \ldots, u_{L-1}\right)^{T}$ dan $\pi_{i}$ adalah komponen terakhir dari eigenvector $\mathrm{U}\left(\pi_{i}=u_{L}\right)$, maka koefisien LRF diperoleh dengan:

$\left(a_{L-1}, a_{L-2}, \ldots, a_{2}, a_{1}\right)^{T}=\frac{1}{1-v^{2}} \sum_{i=1}^{r} \pi_{i} U_{i}^{\bar{v}}$

dimana $v^{2}=\sum_{i=1}^{r} \pi_{i}^{2}$

\section{HASIL DAN PEMBAHASAN}

Secara deskriptif, data produksi cabai merah di Jawa Barat disajikan dalam Tabel 1.

Tabel 1. Hasil Gambaran Umum Produksi Cabai Merah di Jawa Barat

\begin{tabular}{|lrrrrrrrr}
\hline \multicolumn{1}{l}{ Descriptive Statistics: produksi } \\
Total \\
Variable & Count & Mean & StDev & Variance & Minimum & Median & Maximum & IQR \\
produksi & 72 & 87069 & 29676 & 880677200 & 35971 & 84688 & 155122 & 38815 \\
\hline
\end{tabular}

Dari hasil di atas dapat diketahui bahwa data penelitian sebanyak 72 data yang merupakan data produksi bulanan mulai Januari 2010 sampai Desember 2015. Data memiliki rata-rata produksi sebesar 87,068 ribu ton. Nilai standart deviasi dan varians sangat besar yaitu 29.676 dan 880677200. Ini menunjukkan bahwa data memiliki variasi yang tinggi juga range yang jauh. Kemudian untuk mengetahui kenormalan pada data dapat dilihat pada histogram data pada Gambar 1.

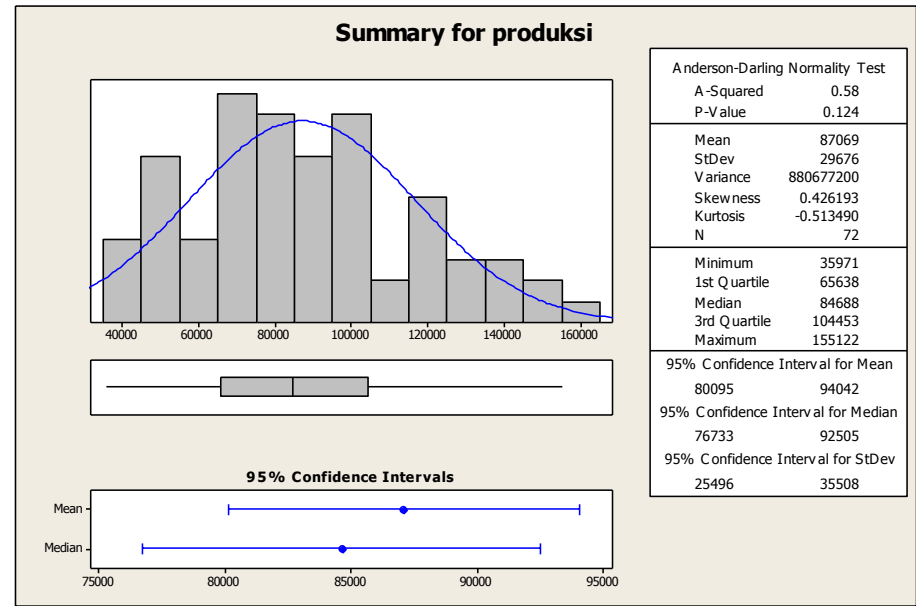

Gambar 1. Graphic Summary Data Produksi Cabai Merah di Jawa Barat 


\section{Asnafiya Asrof dkk.}

Berdasarkan Gambar 1, dapat diketahui bahwa nilai p-value dari uji normalitas AndersonDarling adalah 0,124. Hal ini berarti bahwa dengan tingkat kepercayaan 5\% ditunjukkan penerimaan hipotesis null yang berarti bahwa rata-rata produksi cabai merah di Jawa Barat bersifat normal.

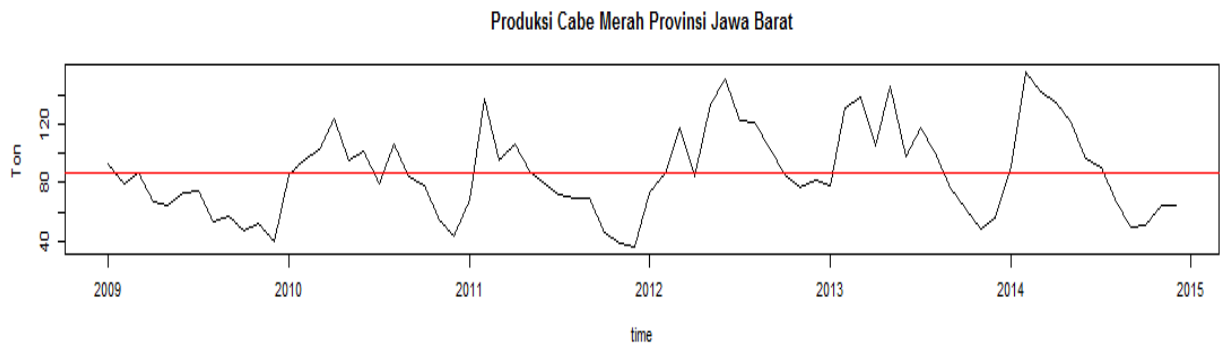

Gambar 2. Pola Data Produksi Cabai Merah di Jawa Barat

Secara grafis (Gambar 2), terlihat bahwa terdapat fluktuasi pada produksi cabai merah di Jawa Barat, sehingga data dapat disimpulkan tidak dipengaruhi pola trend dan mengandung pola musiman aditif. Data produksi cabai tersebut juga menunjukkan bahwa perubahannya masih terbilang stabil, sehingga dapat dikatakan bahwa data sudah stasioner terhadap mean.

Selanjutnya adalah melakukan identifikasi adanya pola musiman. Sering kali data yang ada kurang jelas dalam memperlihatkan pola musiman seperti pada data produksi cabai merah. Untuk itu diperlukan suatu analisis penaksiran dalam kawasan frekuensi untuk menelaah periodisitas tersembunyi yaitu periodisitas yang sulit ditemukan dalam kawasan waktu. Analisis ini disebut dengan analisis spektral. Data produksi cabai merah diketahui bersifat stasioner, maka dapat langsung dilakukan analisis spektral. Pengujian musiman dengan analisis spektral diperoleh hasil bahwa data produksi cabai merah memiliki periode sebesar 12 . Adapun penaksiran parameter differencing (d) data produksi cabai merah menggunakan regresi spektral dengan metode Geweke dan Porter Hudok (GPH) dengan RStudio diperoleh nilai d sebesar 0,24.

Pemodelan untuk meramalkan produksi cabai merah di Jawa Barat dengan metode SSA. Model ini menguraikan data menjadi komponen-komponennya yaitu trend, musiman, siklis dan komponen acak. Tahapan yang dilakukan dalam metode ini terbagi dua yakni dekomposisi dan rekonstruksi.

\section{Model Peramalan SSA}

\section{Dekomposisi}

Tabe1 2. Pemilihan Window Length Model Singular Spectrum Analysis (SSA)

\begin{tabular}{cc}
\hline Window Length & MAPE(\%) \\
\hline 5 & 43,14 \\
\hline 6 & 18,23 \\
\hline 8 & 72 \\
\hline 9 & 46,74 \\
\hline 12 & 41,53 \\
\hline 15 & 51,57 \\
\hline 18 & 43,14 \\
\hline 20 & 40,57 \\
\hline 24 & 36,04 \\
\hline
\end{tabular}


Langkah awal yang harus dilakukan sebelum memasuki langkah-langkah dalam tahap dekomposisi adalah menentukan window length dengan cara trial and error. Nilai window length berada pada rentang $1<L \leq N / 2$.

Berdasarkan Tabel 2, dengan nilai MAPE minimum, maka pemilihan window length yang terbaik adalah sebesar 6.

Langkah awal dalam dekomposisi ini adalah embedding yang menghasilkan matriks lintasan berukusan $L \times K$. Diperoleh bahwa nilai $L=6$, sehingga $K=55$. Dimensi matriks lintasannya adalah berukuran 6 x 55 yang kemudian menghasilkan matriks berikut.

$$
X_{i, j(6 \times 55)}=\left[\begin{array}{cccc}
93119 & 79108 & \cdots & 117180 \\
79108 & 86869 & \cdots & 100836 \\
86869 & 67671 & \cdots & 76642 \\
67671 & 64382 & \cdots & 61750 \\
64382 & 72825 & \cdots & 49171 \\
72825 & 74164 & \cdots & 56368
\end{array}\right]
$$

Tahap selanjutnya dalam dekomposisi ini adalah Singular Value Decomposition (SVD) yang menghasilkan eigenvalue, pasangan eigenvalue, dan matriks W-correlation yang ditampilkan bersama bentuk grafiknya. Grafik-grafik berikut akan menjadi dasar dalam grouping pada tahapan selanjutnya.

a. Singular Value $\left(\sqrt{\lambda_{i}}\right)$

Singular value merupakan akar kuadrat dari eigenvalue. Hasil eigenvalue diperoleh dari matriks trajectory yang didefinikan dengan $S=X X^{\prime}$.

Tabel 3. Hasil Singular Value Produksi Cabai Merah di Jawa Barat

\begin{tabular}{lc}
\hline $\mathrm{L}$ & Singular Value \\
\hline 1 & 1619301,3 \\
\hline 2 & 280567,2 \\
\hline 3 & 161837,0 \\
\hline 4 & 118455,5 \\
\hline 5 & 111290,8 \\
\hline 6 & 108861,8 \\
\hline
\end{tabular}

b. Eigenvector $U_{i}$,

Langkah selanjutnya adalah untuk mendapatkan eigenvector. Hal ini dilakukan untuk mempermudah penentuan karakteristik data dari matriks trajectory.

$$
U_{i}=\left[\begin{array}{cccccc}
-0.4044886 & 0.5373397 & 0.54387296 & -0.2624964 & 0.2001041 & 0.3780360 \\
-0.4104105 & 0.4193766 & -0.08009298 & 0.5274320 & -0.5495218 & -0.2628933 \\
-0.4137259 & 0.1668921 & -0.43478443 & -0.4689571 & 0.3098949 & -0.5440448 \\
-0.4120444 & -0.1578383 & -0.44467749 & 0.4268511 & 0.4251872 & 0.4945527 \\
-0.4074077 & -0.4230581 & -0.10709317 & -0.4475313 & -0.5847924 & 0.3182851 \\
-0.4012746 & -0.5510402 & 0.54730504 & 0.2247313 & 0.1979469 & -0.3822348
\end{array}\right]
$$

Berikutnya adalah principal component. Tahap ini dilakukan dengan nilai singular value dan eigenvectors yang telah diperoleh dari matriks trajectory.

$$
V_{i(55 \times 6)}=\left[\begin{array}{cccccc}
-189408,3 & 19662,4 & 9410,5 & -7018,6 & 7620,4 & -6732,8 \\
-181605,3 & 8394,0 & 10806,9 & 4874,2 & -11468,3 & -3076,3 \\
\vdots & \vdots & \vdots & \vdots & \vdots & \vdots \\
-188586,4 & 56434,9 & 20457,8 & 3503,2 & 445,9 & 735,7
\end{array}\right]
$$




\section{Asnafiya Asrof dkk.}

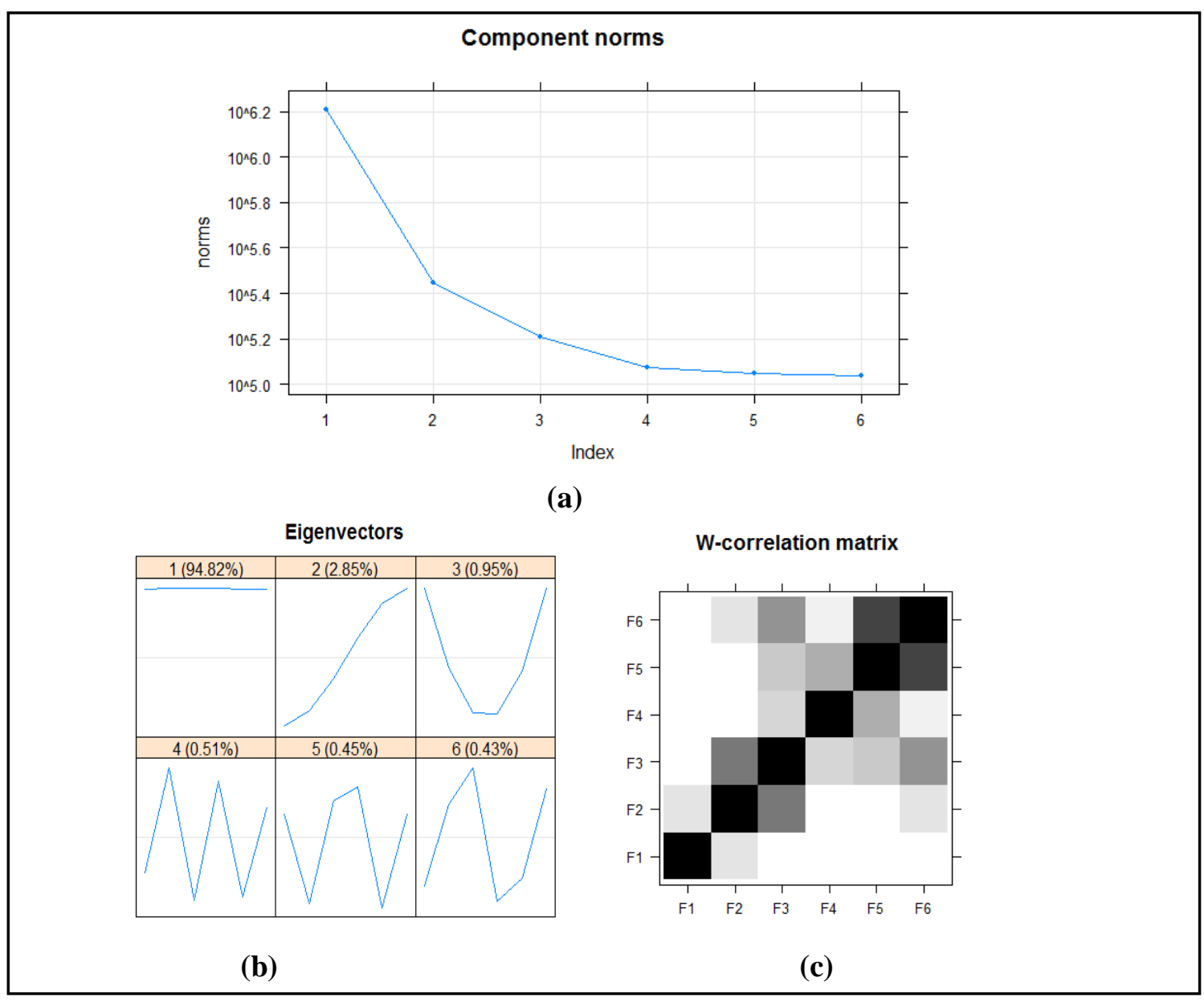

Gambar 3. (a) Grafik Eigen Value (b) Grafik Eigen Vector (c) Matriks W-Correlations

\section{Rekonstruksi}

Pada tahap ini, jumlah group yang ditetapkan saat efek grouping adalah sebanyak 4 grup. Selanjutnya keempat grup ini akan dijadikan sebagai parameter dalam tahap rekonstruksi. Terdapat 2 langkah dalam tahap ini yaitu grouping dan diagonal averaging. Pada tahap diagonal averaging, grup-grup tersebut dipilih untuk direkonstruksi kembali menjadi deret baru. Hasil rekonstruksi produksi cabai merah pada tahap grouping dan diagonal averaging disajikan pada Tabel 4.

Tabel 4. Hasil Rekonstruksi Produksi Cabai Merah di Jawa Barat

\begin{tabular}{ccccccc}
\hline \multirow{2}{*}{ Data ke } & Data & Pola 1 & Pola 2 & Pola 3 & Pola 4 & $\begin{array}{c}\text { Diagonal } \\
\text { Averagin } \\
\end{array}$ \\
\cline { 2 - 7 } $\boldsymbol{g}$
\end{tabular}


Berdasarkan kedekatan dan kemiripan bentuk grafik hasil dari rekonstruksi dapat dilihat pada Gambar 4.

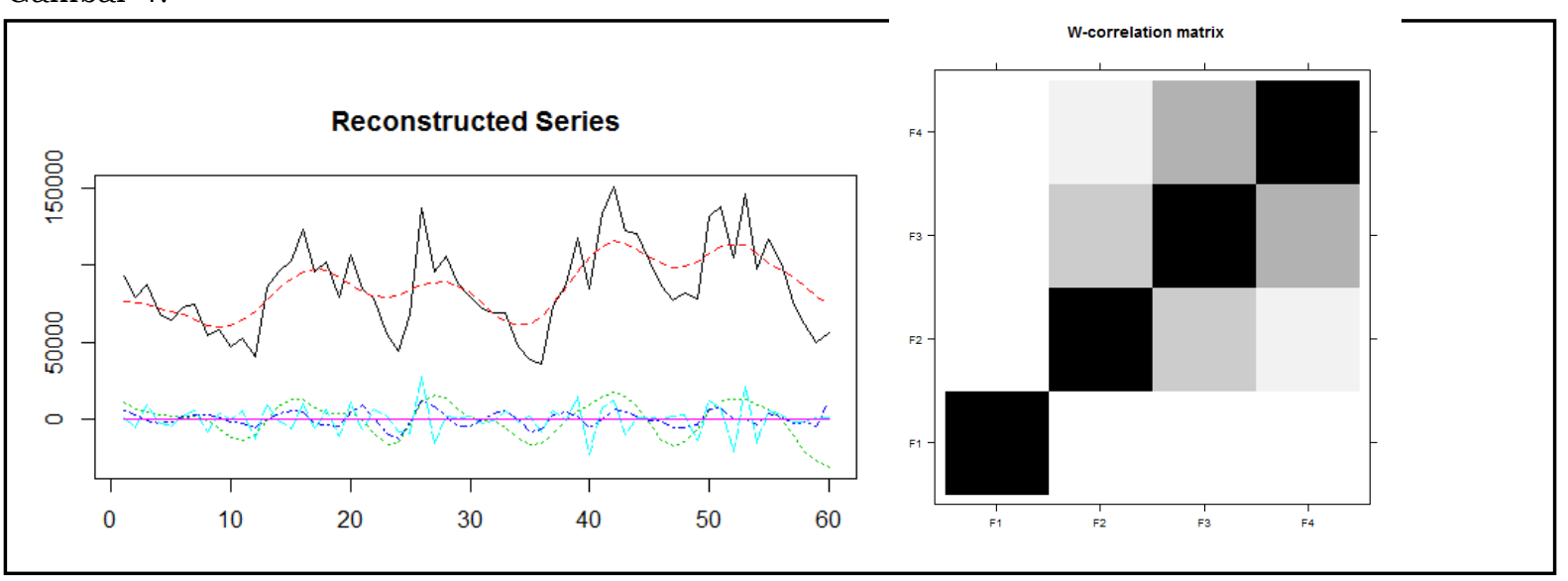

Gambar 4. Hasil Rekonstruksi Tahap Grouping; dan Matriks W-Correlation Setelah Rekonstruksi

\section{Peramalan Produksi Cabai Merah dengan Model Terbaik}

Tahapan selanjutnya akan dilakukan peramalan produksi cabai merah untuk 12 periode kedepan (periode Januari s/d Desember 2016) dengan metode SSA. Hasil peramalannya disajikan dalam Tabel 5.

Tabe1 5. Ramalan Produksi Cabai Merah Provinsi Jawa Barat Periode Jan-Des 2016

\begin{tabular}{cc}
\hline Periode & Hasil Ramalan (Kuintal) \\
\hline Januari 2016 & $96.974,77$ \\
\hline Februari 2016 & $110.101,54$ \\
\hline Maret 2016 & $109.884,00$ \\
\hline April 2016 & $89.427,47$ \\
\hline Mei 2016 & $60.200,92$ \\
\hline Juni 2016 & $38.579,92$ \\
\hline Juli 2016 & $33.835,70$ \\
\hline Agustus 2016 & $43.393,74$ \\
\hline September 2016 & $58.825,24$ \\
\hline Oktober 2016 & $77.014,60$ \\
\hline November 2016 & $96.314,05$ \\
\hline Desember 2016 & $110.161,92$ \\
\hline
\end{tabular}

\section{Ketepatan Pencapaian Model}

\section{Mean Absolute Persentage Error (MAPE)}

Data produksi cabai merah di Jawa Barat memiliki window length sebesar 6 pada proses trial dan error. Sehingga diperoleh MAPE sebesar 18,23\%. Hal ini dapat disimpulkan bahwa metode peramalan dengan menggunakan singular spectrum analysis (SSA) dengan window length sebesar 6 dikatakan baik dalam meramalkan produksi cabai merah di Jawa Barat. 


\section{Asnafiya Asrof dkk.}

\section{Linear Recurrent Formula (LRF)}

Tahap selanjutnya adalah melakukan peramalan berdasarkan model yang telah terbentuk. Hasil peramalan dengan metode reccurent yang diperoleh akan dibandingkan dengan data out sample untuk validitas model. Model ramalannya adalah sebagai berikut.

$g_{i}=\left\{\begin{array}{cc}\tilde{y}_{i} & \text { untuk } 0, \cdots, 60 \\ \sum_{j=1}^{L-1} a_{j} g_{i-j} & \text { untuk } 61, \cdots, 84\end{array}\right.$

Dengan nilai koefisien LRF $a_{j}$ disajikan dalam Tabel 6.

Tabel. 6. Koefisien Linear Recurrent Formula $\left(a_{j}\right)$

\begin{tabular}{cc}
\hline No & $\boldsymbol{a}_{\boldsymbol{j}}$ \\
\hline 1 & $-0,0212$ \\
\hline 2 & $-0,0539$ \\
\hline 3 & $-0,0594$ \\
\hline 4 & $-0,0372$ \\
\hline 5 & 0,0037
\end{tabular}

Setelah diperoleh koefisien LRT, maka hasil peramalannya disajikan dalam Tabel 7.

Tabe1 7. Data Aktual dan Hasil Ramalan Model SSA

\begin{tabular}{ccc}
\hline Periode & Data Aktual (Ton) & $\begin{array}{c}\text { Hasil Ramalan } \\
\text { (Kuintal) }\end{array}$ \\
\hline 1 & 90.164 & $77.755,33$ \\
\hline 2 & 155.122 & $87.696,02$ \\
\hline 3 & 141.448 & $98.861,29$ \\
\hline 4 & 134.147 & $107.898,52$ \\
\hline 5 & 120.701 & $114.566,70$ \\
\hline 6 & 96.275 & $93.182,65$ \\
\hline 7 & 90.332 & $65.549,80$ \\
\hline 8 & 66.847 & $46.355,86$ \\
\hline 9 & 49.809 & $42.470,39$ \\
\hline 10 & 51.178 & $53.446,72$ \\
\hline 11 & 65.235 & $66.507,85$ \\
\hline 12 & 65.156 & $81.003,18$ \\
\hline
\end{tabular}

\section{KESIMPULAN}

Berdasarkan hasil penelitian mengenai Model Peramalan Time series untuk Produksi Cabai Merah, dapat diambil kesimpulan yaitu:

1. Data produksi cabai merah di Jawa Barat ini merupakan data periodik dengan keperiodikan tahunan atau 12 bulan. Peramalan yang dilakukan dengan metode SSA ini memberikan kelompok produksi cabai merah menjadi 4 kelompok, dimana hasil peramalan untuk periode Januari 2016 sampai Desember 2016 ditampilkan pada Tabel 5. 
2. SSA merupakan metode time series terbaik dalam meramalkan produksi cabai merah di Jawa Barat dimana ketinggian tingkat akurasinya dilihat dari nilai MAPE terkecil, yaitu sebesar 18,23\% dengan window length sebanyak 6.

3. Berdasarkan hasil peramalan pada Tabel 5, produksi cabai merah di Jawa Barat pada bulan Juli 2016 terbilang paling rendah selama enam tahun terakhir. Hal ini tentunya akan berdampak pada kenaikan harga cabai yang melambung tinggi di pasaran. Sedangkan produksi cabai pada bulan Februari dan Desember 2016 terbilang cukup dibanding bulan-bulan lainnya di tahun 2016 yang mengalami penurunan produksi cabai merah.

4. Total produksi cabai merah di Jawa Barat pada tahun 2016 adalah $924.713,87$ kuintal. Produksi cabai merah ini mengalami penurunan dibanding taun sebelumnya, seiring meningkatnya konsumen cabai merah di Jawa Barat.

\section{DAFTAR PUSTAKA}

Budiman, Asep. 2016. Gerakan Tanam Cabai di Pekarangan Tingkatkan Produksi Nasional. Online: http://www.pikiran-rakyar.com/ekonomi/2016/11/22/gerakan-tanam-cabai-di pekarangan-tingkatkan-produksi-nasional-385487.

Golyandina, N et al. 2001. Analysis of Time Series Structure: SSA and Related Techniques. Chapman\&Hall/CRC

Golyandina and Zhigljavsky. 2013. Basic Singular Spectrum Analysis and Forecasting with $R$. Computational Statistics and Data Analysis 71 (2014) 934-954.

Marwati, A.S. 2012. Perbandingan Stabilitas Hasil Peramalan Suhu R dan V Forecasting SSA Untuk Long Horizon. Tesis. Fakultas MIPA, Universitas Padjajaran. Bandung.

Darmawan,G. 2016. Identifikasi Pola Data Curah Hujan Pada Proses Grouping dalam Metode Singular Spectrum Analysis. Prosiding. Seminar Nasional Pendidikan Matematika. ISSN: 2528-4630. Hal: 1-9.

Darmawan, G.dkk. 2015. Model Auto Singular Spectrum Untuk Meramalkan Kejadian Banjir Di Bandung Dan Sekitarnya. Seminar Nasional Matematika dan Pendidikan Matematika UNY. Hal. 457-462.

Data Produksi Cabai Merah di Jawa Barat dari Badan Pusat Statistik Provinsi Jawa barat. 